\title{
A clinicopathological study of ocular involvement in primary hyperoxaluria type $\mathrm{I}^{\star}$
}

\author{
Kent W Small, Jon Scheinman, Gordon K Klintworth
}

\begin{abstract}
We performed a clinicopathological study on the eyes of a 3-year-old girl with primary hyperoxaluria type I. An examination one year before death disclosed a slightly diminished visual acuity in both eyes with black, geographic central macular, subretinal patches. Calcium oxalate was deposited predominantly in the retinal pigment epithelium of the posterior pole, where these cells were markedly hyperplastic and hypertrophied round foci of oxalate crystals. Oxalate crystals were exceedingly sparse in other ocular structures and when present were not associated with an apparent tissue reaction in these other locations. A collagenous layer was evident between parts of the retinal pigment epithelium and the neurosensory retina, which contained occasional perivascular clumps of melanin laden cells. The predominant deposition of oxalate in the retinal pigment epithelium, with the exuberant response of these cells around the crystals, gives a clue to the pathogenic mechanisms of primary hyperoxaluria.
\end{abstract}

Calcium oxalate crystals may be deposited in the kidneys, eyes, bones, joints, skin, cardiac conduction system, and other tissues as a primary or secondary phenomenon. The term primary hyperoxaluria (primary oxalosis) refers to two rare genetic inborn errors of metabolism characterised by nephrocalcinosis, recurrent calcium oxalate nephrolithiasis, and an excessive urinary excretion of oxalic acid. Early diagnosis can be suspected by the finding of increased echogenicity of the renal papillae on ultrasonography before nephrocalcinosis is detectable on routine roentgenograms of the abdomen. Primary hyperoxaluria may be particularly severe when it presents during infancy with acute renal failure.

Primary hyperoxaluria type I (McKusick 259900) (glycolic aciduria) is typified by an excessive urinary excretion of glyoxylic and glycolic acids and is due to a deficiency of alanine:glyoxylate aminotransferase (AGAT) (Fig 1). The AGAT gene has recently been sequenced' and the mutation predicted to cause the disease in one-third of all patients with primary hyperoxaluria type I has been identified. The manifestations of primary hyperoxaluria type I vary markedly. ${ }^{2}$ This autosomal recessive disease usually becomes clinically evident during childhood or early adulthood with urolithiasis leading to end stage renal failure. A retinopathy characterised by tiny yellow glistening specks ('flecked' retina, crystalline retinopathy) or by

$\star$ Presented in part at the International Society of Ophthalmic Pathologists, New Orleans, LA, USA, October 1989.

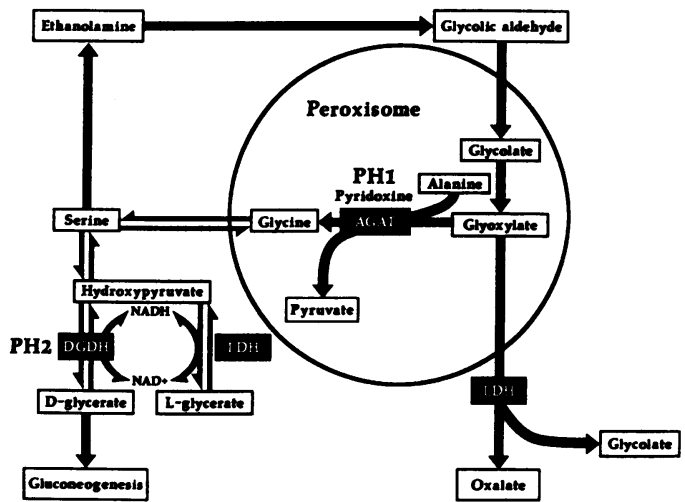

Figure 1 Metabolic pathways for primary hyperoxaluria type $1(P H 1)$ deficient peroxisomal alanine:glyoxylate aminotransferase and primary hyperoxaluria type 2(PH2) deficient extraperoxisomal D-glyceric acid dehydrogenase. $D G D H=D$-glyceric acid dehydrogenase, $L D H=$ lactate dehydrogenase. $A G A T=$ alanine: glycoxylate aminotransferase. $N A D H=$ reduced nicotinamide adenine dinucleotide. $N A D+=$ nicotinamide adenine dinucleotide.

large black geographic submacular lesions has been noted in one-third of patients with primary hyperoxaluria type $\mathrm{I}^{3-13}$ End stage renal failure has invariably preceded or occurred concurrently with this funduscopic appearance, which has usually been limited to the posterior pole.

In a clinical series of 24 patients with primary hyperoxaluria we have previously shown the extreme clinical variability in the funduscopic appearance. ${ }^{13}$ One of the patients from our series died, and in this communication we report the histopathological findings in the two eyes that were obtained post mortem and compare them with those in previous studies.

\section{Case report}

The patient, a girl, was born weighing $3912 \mathrm{~g}$, after an uncomplicated pregnancy and delivery to a healthy primigravida mother. She was healthy and developed normally until 8 months old, when she presented with weight loss, anorexia, and lethargy and was found to have primary hyperoxaluria type I with anuric renal failure. Treatment was begun with intensive haemodialysis, supplemental pyridoxine, electrolyte manipulations, and dietary restriction of oxalate and ascorbate according to our previously described protocol. ${ }^{14}$ At 15 months of age a renal transplantation was performed with a living relative as a donor.

The patient gradually developed recurrence of calcium oxalate in her renal graft and died two years later of renal failure. At 2 years of age we performed an ophthalmic examination, which has been previously reported ${ }^{13}$ (Fig 2). An electroretinogram was normal.

\author{
Ophthalmology, Medical \\ 171 Ashley Avenue, \\ Charleston, SC 29425-2236, \\ Accepted for publication \\ 28 February 1991 \\ G K Klintworth \\ Correspondence to: \\ Kent W Small, MD \\ Department of
}



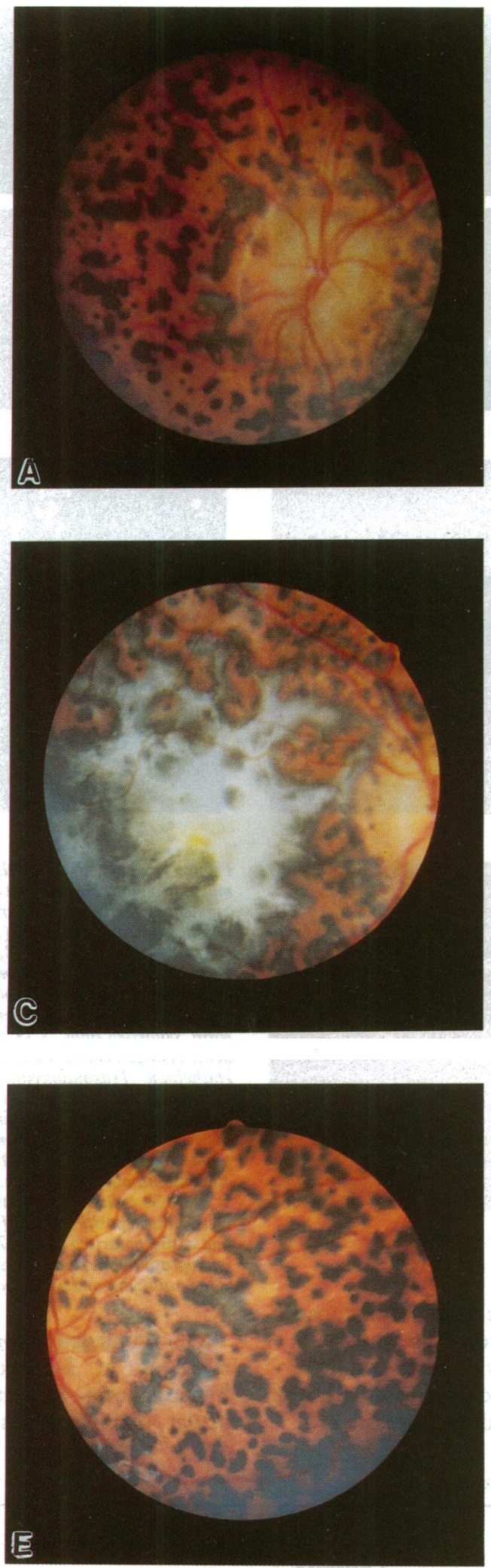

\section{Results}

Histopathological examination of the eyes disclosed numerous, pitch black foci in the posterior portion of the fundus (Fig 2). By light microscopy these dense black foci consisted of multiple layers of hyperplastic and hypertrophic retinal pigment epithelium (Fig 3). Numerous calcium oxalate crystals were present within the clumps of retinal pigment epithelial cells and were dramatically demonstrated when viewed
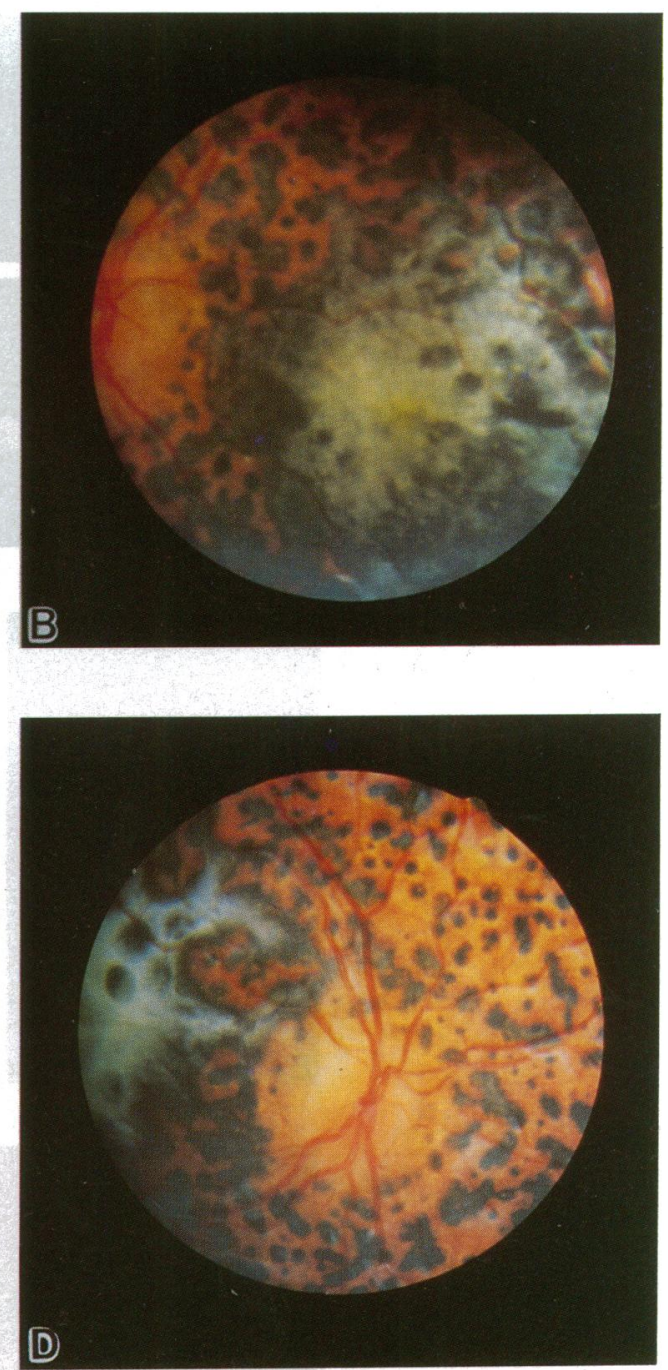

Figure 2 Examination of the fundus of both eyes disclosed abnormal pigmentation. A: spots and patches of black retinal pigment can be seen in the nasal retina of the left eye. B: dense geographic patch of retinal pigment epithelium with fine white material interposed between retinal pigment epithelium and neurosensory retina of the left macula. C: the macula of the right eye closely resembles that of the other eye. D: right eye, optic disc, $E$, nasal retina of right eye, black spots due to retinal pigment epithelium hyperplasia and patches less numerous towards periphery. (Reproduced by permission from Arch Ophthalmol 1990; 108: 89-93. Copyright 1990, American Medical Association.

under polarised light because of their birefringence. Some crystals in the retinal pigment epithelium stained with alizarin red at $\mathrm{pH} 7.0$ but not at $\mathrm{pH} 4 \cdot 2$, thus confirming that the crystals were composed of calcium oxalate. ${ }^{15}$ Very few birefringent crystals were noted in the pigment epithelium anterior to the equator of the eye. A collagenous layer was evident on the surface of some reactive retinal pigment epithelial cells in the macula. Choroidal neovascularisation was not present.

Most of the overlying neurosensory retinal and other ocular structures were normal except for autolytic degeneration of the photoreceptors.

Liver tissue, analysed by Professor C Danpure, showed no alanine:glyoxylate aminotransferase activity, confirming the diagnosis of primary hyperoxaluria type I. 

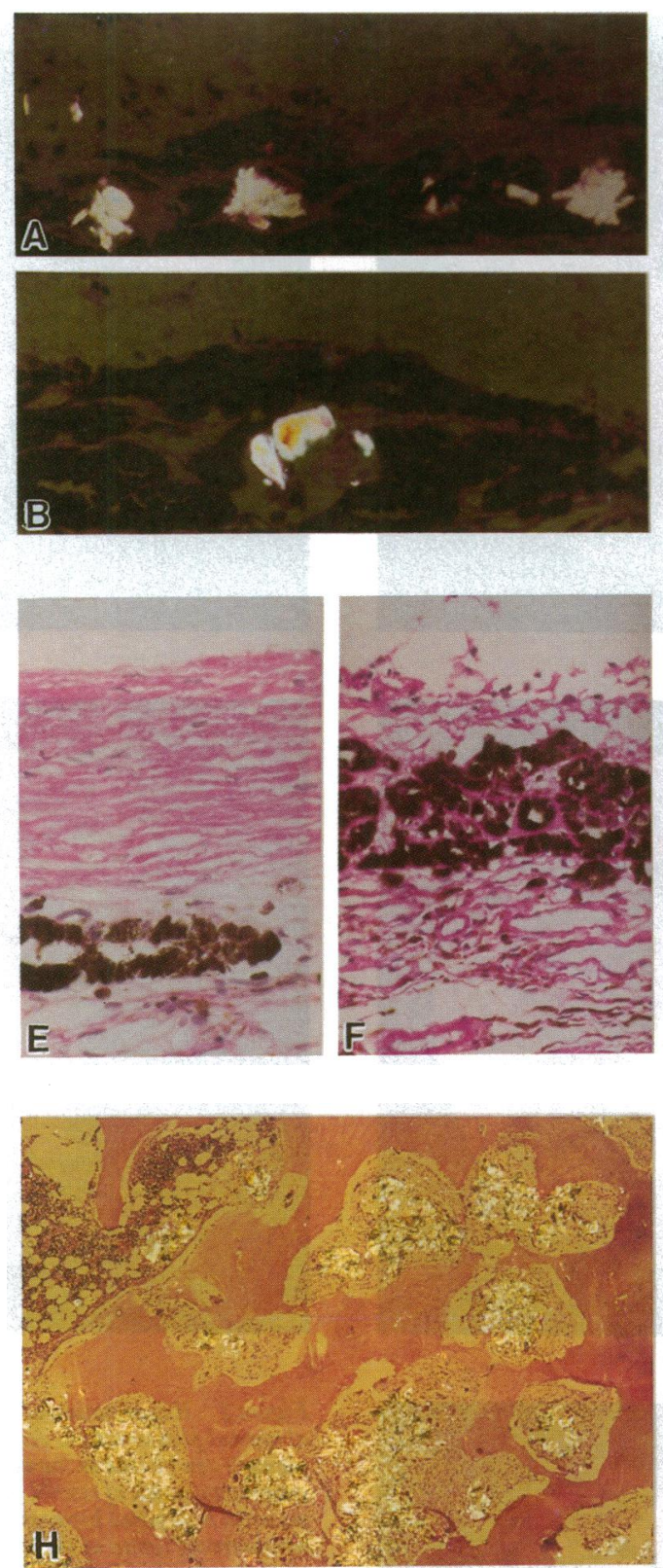

\section{Discussion}

In addition to our case we know of histopathological reports on the eyes of seven cases of primary hyperoxaluria reviewed in Table $1 . .^{16-20}$ None have reported choroidal neovascularisation as was previously suggested by Meredith et al. ${ }^{19}$
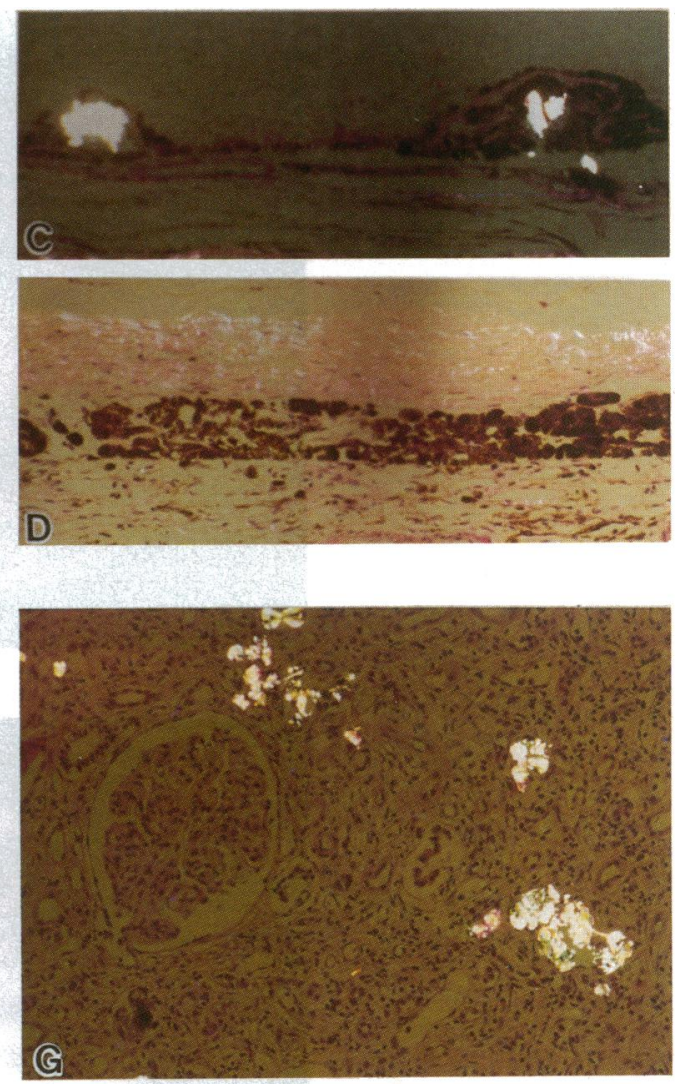

Figure $3 A, B$, and C: polarised light micrograph of macular region, birefringent crystals at level of retinal pigment epithelium with marked hyperplasia/hypertrophy of retinal pigment epithelium. (Haematoxylin and eosin, polarised light, $A, \times 140 ; B, \times 125 ; C, \times 21)$. D: partially polarised light micrograph, macula, exuberant retinal pigment epithelium reaction; collagen layer (also birefringent) on inner surface of retinal pigment epithelium. (Haematoxylin and eosin, polarised light, $\times 53$.) E: light micrograph, macula, dense collagen network overlying reactive retinal pigment epithelium. (Haematoxylin and eosin, $\times 106$.) F: light micrograph, macula, less collagen on surface of retinal pigment epithelium, remaining marked hypertrophy/ hyperplasia of retinal pigment epithelium 'lacunae' in retinal pigment epithelium represent oxalate crystals which are not evident without polarisation. (Haematoxylin and eosin, $\times 106$.) G: polarised light micrograph, kidney, dense crystalline deposition, loss of tubules, fibrosis. (Haematoxylin and eosin, polarised light $\times 70$.) $H$ : polarised light micrograph, bone, dense crystalline deposition, hyperostosis. (Haematoxylin and eosin, polarised light, $\times 28$.)

Our clinicopathological investigation of the eyes of a 3-year-old girl with primary hyperoxaluria further illustrates the diverse ocular manifestations of the disease. To our

Table 1 Pathological reports on ocular findings in primary hyperoxaluria

\begin{tabular}{|c|c|c|c|c|c|c|c|c|c|}
\hline \multirow[b]{2}{*}{ Case } & \multirow[b]{2}{*}{ Reference } & \multirow[b]{2}{*}{ Years } & \multirow[b]{2}{*}{$\begin{array}{l}\text { Age at onset } \\
\text { of symptoms }\end{array}$} & \multirow[b]{2}{*}{$\begin{array}{l}\text { Renal } \\
\text { failure }\end{array}$} & \multirow[b]{2}{*}{$\begin{array}{l}\text { Renal } \\
\text { transplant }\end{array}$} & \multirow[b]{2}{*}{$\begin{array}{l}\text { Age at } \\
\text { death }\end{array}$} & \multirow[b]{2}{*}{$\begin{array}{l}\text { Funduscopic } \\
\text { findings in } \\
\text { posterior pole }\end{array}$} & \multicolumn{2}{|l|}{ Pathological findings } \\
\hline & & & & & & & & Crystal locations & $\begin{array}{l}R P E \\
\text { hyperplasia }\end{array}$ \\
\hline 1 & Scowen et $\mathrm{l}^{16}$ & 1959 & 1 year & Yes & No & 23 years & Not described & Ciliary body (scanty) & No \\
\hline 2 & Timm $^{12}$ & 1963 & Childhood & Yes & No & 23 years & Not described & $\begin{array}{l}\text { Extraocular muscles, lacrimal glands, ciliary body, } \\
\text { choroid, retina, optic nerve (especially vessels) }\end{array}$ & No \\
\hline $\begin{array}{l}3 \\
4\end{array}$ & $\begin{array}{l}\text { Timm } \\
\text { Toussaint } \\
\text { et } a l^{17}\end{array}$ & $\begin{array}{l}1976 \\
1976\end{array}$ & $\begin{array}{l}\text { Not stated } \\
10 \text { years }\end{array}$ & $\begin{array}{l}\text { Yes } \\
\text { Yes }\end{array}$ & $\begin{array}{l}\text { Yes } \\
\text { Yes }\end{array}$ & $\begin{array}{l}26 \text { years } \\
33 \text { years }\end{array}$ & $\begin{array}{l}\text { Flecked retina } \\
\text { Flecked retina }\end{array}$ & $\begin{array}{l}\text { RPE, sensory retina, ciliary body } \\
\text { RPE ciliary body }\end{array}$ & $\begin{array}{l}\text { No } \\
\text { No }\end{array}$ \\
\hline $\begin{array}{l}5 \\
6\end{array}$ & $\begin{array}{l}\text { Fielder et } a l^{18} \\
\text { Meredith } \\
\text { et } a l^{19}\end{array}$ & $\begin{array}{l}1980 \\
1984\end{array}$ & $\begin{array}{l}5 \text { months } \\
6 \text { months }\end{array}$ & $\begin{array}{l}\text { Yes } \\
\text { Yes }\end{array}$ & $\begin{array}{l}\text { No } \\
\text { No }\end{array}$ & $\begin{array}{l}6 \text { months } \\
7 \text { months }\end{array}$ & $\begin{array}{l}\text { Fleck retina } \\
\text { 'Ring of yellowish } \\
\text { lesions' }\end{array}$ & $\begin{array}{l}\text { RPE } \\
\text { RPE, iris sensory retina, ciliary body, conjunctiva }\end{array}$ & $\begin{array}{l}\text { No } \\
\text { No }\end{array}$ \\
\hline $\begin{array}{l}7 \\
8\end{array}$ & $\begin{array}{l}\text { Speiser et al } \\
\text { Small, } \\
\text { Scheiman, } \\
\text { Klintworth }\end{array}$ & $\begin{array}{l}1988 \\
1991\end{array}$ & $\begin{array}{l}4 \text { months } \\
9 \text { months }\end{array}$ & $\begin{array}{l}\text { Yes } \\
\text { Yes }\end{array}$ & $\begin{array}{l}\text { No } \\
\text { Yes }\end{array}$ & $\begin{array}{l}3 \text { years } \\
3 \text { years }\end{array}$ & $\begin{array}{l}\text { Black ringlets } \\
\text { Black geographic } \\
\text { lesions }\end{array}$ & $\begin{array}{l}\text { RPE sensory retina } \\
\text { RPE }\end{array}$ & $\begin{array}{l}\text { Mild } \\
\text { Marked }\end{array}$ \\
\hline
\end{tabular}


knowledge this is the first histopathological report of a patient with enzymatically confirmed primary hyperoxaluria type I. In contrast to previously reported cases, the eyes of our patient were characterised by: (1) an exuberant retinal pigment epithelial reaction round the crystals which was seen funduscopically as geographic black lesions; (2) the collagenous layer between the retinal pigment epithelial cells and the neurosensory retina which correlated with the clinically apparent thin white layer located between the neurosensory retina and the retinal pigment epithelium; and (3) the paucity of oxalate crystals in the remaining ocular structures.

We acknowledge the pioneering biochemical and molecular genetic work of Christopher Danpure on this disease and thank genetic work of Christopher Danpure on this disease

This work was supported in part by Research Grant RO1EYO147 from the National Eye Institute.

Purdue PE, Takada Y, Danpure CJ. Identification of mutation associated with peroxisome to mitochondrial mistargeting of alanine/glyoxylate aminotransferase in primary hyperoxaluria type I. $f$ Cell Biol 1990 ; 111: 2341-51.

2 Leumann EP, Niederwieser A, Fanconi A. New aspects of infantile oxalosis. Pediatr Nephrol 1987; 1: 531-5.

3 Buri JF. L'oxalase. Présentation clinique d'une observation avec revue de la litterature et discussion diagnostique. Recherches biochimiques et metaboliques. Helv Paediat Acta 1962; 17 (suppl): 11 .

4 Zak TA, Buncic R. Primary hereditary oxalosis retinopathy Arch Ophthalmol 1983; 101: 78-80.
5 Gottleib RP, Ritter JA. 'Fleck retina' an association with primary hyperoxaluria. $\mathcal{F}$ Pediatr 1977; 90: 939-42.

6 Welt R, Doden W, Thiers G. Augen- und Hautmanifestationen bei endogener Oxalose des protrahierten Typs (Verlauf beobachtung). Klin Monatsbl A ugenheilkd 1986; 189: 158-60

7 Traboulsi EI, El-Baba F, Barakat AY, Faris BM. The retinopathy of primary hyperoxaluria. Retina 1985; 5 : 151-3.

8 Langmann A, Fellinger C. Ein Fall von Retinopathia oxalogenica und Cytomegalie-Infection. Klin Monatsbl Augenheilkd 1985; 187: 437-8.

9 Gass JDM. Stereoscopic atlas of macular diseases. 3rd ed. St Louis: Mosby, 1987: 302.

10 Besio R, Meerhoff E, Laza J, Venturini A. Oxalosis. Am 7 Ophthalmol 1983; 95: 397-8.

11 Timm G. Den Krankheitsbild der Retinopathia oxalogenica. Klin Monatsbl Augenheilkd 1976; 168: 537-43.

12 Timm G. Oxalose und Auge. Ophthalmologica 1963; 146: 1-8.

13 Small KW, Letson R, Scheinman J. Ocular findings in primary hyperoxalura. Arch Ophthalmol 1990; 108: 89-93.

14 Scheinman JI, Najarian JS, Mauer SM. Successful strategie for renal transplantation in primary hyperoxaluria. Kidney Int 1984; 25: 804-11.

15 Proia A, Brinn NT. Identification of calcium oxalate crystals using alizarin red S stain. Arch Pathol Lab Med 1985; 109; 186-90.

16 Scowen EF, Stansfield AG, Watts RWE. Oxalosis and primary hyperoxaluria. F Pathol Bacteriol 1959; 77: 195-205.

17 Toussaint D, Vereerstraeten P, Goffin P, Vanlanduyt P, Jedwab J, Legrand JM. Hyperoxalurie primaire. Etude clinique, histologique et cristallographique des lésions clinique, histologique et cristallographique des
oculaires. Arch Ophtalmol (Paris) 1976; 36: 97-112.

18 Fielder AR, Garner A, Chambers TL O festations of primary oxalosis. Br $\mathcal{F}$ Ophthalmol 1980; 64: 782-8.

19 Meredith TA, Wright JD, Gammon A, Fellner SK, Warshaw $\mathrm{BL}$, Maid M. Ocular involvement in primary hyperoxaluria Arch Ophthalmol 1984; 102: 584-7.

20 Speiser P, Landolt E, Leuman E, Briner J. Augenveranderungen bei der infantilen Oxalose (primaren Hyperoxalurie Typ 1). Klin Monatsbl Augenheilkd 1988; 192: 492-4. 